\title{
NEOLOGISMS AND NONCE EXPRESSIONS OF ETHNIC POLITICS IN NIGERIA'S “CHANGE” REGIME
}

\author{
Chinwe Rose Ann Ezeifeka* \\ http://dx.doi.org/10.4314/og.v14i1.1
}

\begin{abstract}
The paper discusses the influx of ethnically skewed neologisms and nonce expressions in the Nigerian print and online media especially in the present political "Change" dispensation. Language has, as one of its primary characteristics, productivity of new lexemes especially in the content words such as nouns, verbs, adjectives and adverbs, which it does through the many word formation processes among which are affixation, coinages, acronyms and compounding, reduplication, conversion, clipping, blending, and others. Using the first four processes of word formation, the paper analyses some new lexical entries into political vocabulary especially in the language use of apex ethnic political leadership in Nigeria as found in purposively sampled print and online media reports and interrogates the underlying power struggles and ideological contestations in these new lexical derivations and formations through critical discourse analysis (CDA). Findings show that these neologisms foreground ethnic identity construction along lines of division and exclusionism with the potential threat to peaceful national dialogue in Nigeria. It is also obvious from the analysis that these new lexical formations are attempts at contesting and subverting the nepotism tendencies allegedly more pronounced among the present leaders. The paper concludes that instead of fanning these divisive propagandist neologisms, political actors and Nigerians as a whole should address fundamental issues of equality, equity, justice and fair play in governance in order to achieve lasting peace in a united deethnicized Nigeria as a way of stemming the tide of the proliferation of negative ethnic lexical production.
\end{abstract}




\subsection{Introduction}

A cursory perusal of current media reports in Nigeria would reveal quite a number of new lexical entries into political and ethnic discourses which readers are inundated with on regular bases. Some of these are simply nonce expressions invented on the spur of the moment to express a particular feeling or situation, but quite a number of them have persisted and have become neologisms. The major motivation of this work is the pervasive influx of these ethnically skewed new lexical entries in national media discourse in the current "change" regime.

The word "change" is said to be constant in all human interaction as societies evolve improved policies to better human conditions. When therefore the ruling party came up with a campaign slogan of "Change", pronounced in the Hausa accent of "Chanji" in imitation of the party's helmsman tonal articulation of the word, Nigerians saw the development as a welcome relief from the alleged corruption and gross mismanagement of the country's resources that were said to punctuate the ousted party's policies in 2015. The word became a household song even as neonates and geriatrics alike sing in unmasked hope to the rhythm of the jingle that is supposed to articulate the new government's approach to governance:

Hear the call

Call to change

Stand out Nigeria

Change is here and it's here to stay

Change begins with me

Oya make we go

Asiyatito

So let change begin from within

Lokachiyayi

Ogeeruola

Change begins with you and me oh ohoh

Change begins with me oh ohoh (repeatedly until dim)

The attraction of this song is its inclusive politics of incorporating the three constitutionally recognized majority ethnic languages of 
Ezeifeka: Neologism and Nonce Expressions...

Nigeria: Hausa, Igbo and Yoruba; and its clarion call to every Nigerian, irrespective of ethnic divide, to have a rethink of our ethnic superiority complex, to go back to our innermost consciousness, self-appraise ourselves, change our hitherto retrogressive attitude and make Nigerians stand out as one united, indivisible entity where corruption, economic recession and insurgency will become history. In fact, the name of the party's flag bearer, who later became the current Nigerian President, means "change position" in Igbo (buhariaonodu). In spite of its sonorous and aesthetic appeal, this jingle, which used to serve as interlude in national news broadcasts, seemed to have disappeared from the national discourse in recent times. What seems to replace this song of hope in the print and online media are observed neologisms that tend to fan ethnic exclusionism and desperation, which decidedly negate the message of the change song.

This paper focuses on these various neologisms in the print and online media that lead to ethnic segregation in the present political dispensation that promises Nigerians change from such discrimination. It should be noted that the present government promised fight against corruption, economic stability and fight against insurgency as their change agenda. The questions that the work will address include: What new lexical formations are observed in the present political dispensation? What morphological or word-formation processes are involved in these neologisms? What possible explanations can be adduced for the influx of these neologisms? How do these neologisms affect ethnic cohesion in Nigeria? What power structures are responsible for these neologisms? What alternatives are available and can be deployed for more inclusive ethnic cohesion and harmony?

\subsection{Conceptual Review}

\subsection{Neologisms}

Neologisms are newly-formed words or expressions, or a new meaning of existing words or expressions that are in the process of entering mainstream usage (Cambridge English Dictionary online). Neologisms represent the dynamic nature of language, as people evolve new ideas, inventions, developments in science, technology, politics, globalization and other such innovations. Neologisms therefore are candidates for critical study as they give clues to the 
level of development in a particular sphere of human interaction. The new political dispensation in Nigeria seems to be saddled with new words credited to apex ethnic leaders that seem to smack of ethnic divisions and rancour. As Bonfiglio (2006) would have it, ethnicity tends to make people see themselves from kinship perspectives excluding others who apparently do not share this blood bond.

Yule (2010: 53) had argued that, rather than the feeling that new lexical entries in language are debasing, "we might prefer to view the constant evolution of new words and new uses of old words as a reassuring sign of vitality and creativeness in the way a language is shaped by the need of its users". However, this work argues that, in addition to contributing to this vitality and creativeness, the observed neologisms in this work are products of ethnic exclusionism, hate, nepotism and balkanization of the corporate existence of the Nigerian nation state.

In the formation of neologisms, Crystal, (2007: 315) talks about what he calls "nonce expressions", a term for a linguistic form which a speaker consciously invents, or accidentally uses to express a thought or idea on just one single occasion, but which may never get into mainstream usage. Nonce words or formations (forms used for just once) usually drop out of use but, on some occasions, they may be adopted by the speech community as stable neologisms.

For a nuanced discussion of neologisms, a detailed conceptual review of the different word formation processes in language is pertinent. A number of them are listed in Yule (2010), Finegan (2004), Quirk and Greenbaum $(1973,2000)$ and others and will be discussed shorly. Concepts like ethnicity and ethnic identity discourse especially as they relate to how neologisms contribute to or complicate these social constructions are germane to these discussions. Change as a constant feature of human negotiation with the conscious and unconscious worlds of existence should be a sought for position as people relate with one another for communal good. Finally, a link will be established between these concepts and media discourse as champion of public interest.

\subsubsection{Word-formation processes}

A number of scholars have identified different word formation processes that allow new lexical entries into the language (Yule, 
Ezeifeka: Neologism and Nonce Expressions...

2010, Quirk \&Greenbaum 1973). Such processes have been listed as those involving affixation, conversion, compounding, reduplication, coinages, borrowing, blending, acronym, clipping backformation, and some that involve multiple processes (Yule, 2010: 52-61). Although these processes may not all be discussed in turns in this paper, our data implicate some of them as responsible in the formation of the neologisms used in ethnic politics in the print and online media.

Languages have inherent and external mechanisms of extending their vocabularies in order to accommodate new ideas and inventions. There are different ways words enter into a language. Finegan (2004: 52) categorizes these into three broad domains: forming new words from existing words and word parts, "borrowing" words from another language and "coining" new words, that is, making them up, "creating" them from the scratch. The first domain constitutes the most powerful and the most diverse word formation processes and languages do this through affixation, conversion or functional shift, compounding, reduplication, hypocorisms, clippings/shortenings, acronyms, blends and backformations. Borrowing from other languages (such as in the case of the word resume borrowed from French to mean curriculum vitae in English) constitute the second major means of lexical creation in language but may not be relevant to this paper because most of the observed words that motivated this paper do not have foreign etymology. The third, coinages, is another means of lexical entry in languages which according to Finegan (2004), it is not very productive. But for this paper, coinages seem to pervade observed neologisms as different print and online media come up with newly coined expressions that seem to sustain ethnic separatist identity construction. . For the purposes of this paper, four of these processes will be discussed and analysed: affixation, compounding, acronyms and coinages of complex nominalizations and hashtags. We shall discuss them briefly.

Affixation implies "fixing" a linguistic feature, usually a morpheme, onto a lexical item in order to form a word. In all of the known morphological processes, affixation is the only one that involves addition of a morpheme onto a word. This addition is defined by two characteristics; first, the form which results from the operation (the derived form) will consist of the base (the form that 
the operation applies to) plus an additional morpheme. Second, the form which is added (the affix), will be constant; it will remain the same whatever base the operation is applied to (Matthews, 2006).

Thus, a lexical item, to which the rule of affixation is applied, is called a base as different from a stem which takes only inflections. A base as defined by Bauer (1983) is any stem or root word form to which an affix of any kind (inflectional or derivational) can be added. It is a term used in morphology to refer to any part of a word form seen as a unit to which an operation of affixation can be applied. Thus a base, in the process of word formation, can derive another word which may become the base for another derivation, making it possible to derive words that are morphologically and semantically complex. Other word formation processes obvious in this work are: compounding which is the combination of two or more free or bound bases; acronyms, the use of first letters of particular naming expression to shorten such names; and lastly coinages which we have categorized into two, based on the outcome of our data: complex nominalizations and hashtags. (For a more detailed reading of word formation processes, read Yule, (2010), Quirk and Greenbaum (1973)). These word formation processes will be analysed to find out how the derived, compounded, coined words and acronyms are significant in the media reports of present day Nigerian politics and the relationships between these formations and ethnic cohesion.

\subsection{Ethnicity}

The word ethnicity,from the Greek word ethnos meaning "nation" (Singh, 2000: 84), may mean many things to many people. Some have linked ethnicity with culture, language, race or kinship affiliations (Ukiwo, 2006; Fishman, 2000, Bonfiglio, 2007; van Dijk, 1993). In equating ethnicity with racism and xenophobia, van Dijk (1993) claims that it is socially constructed by the power elite just like other sociolinguistic variables of gender, social class and race. To him, the link of ethnicity and racism with kinship ties leads to exaggeration of ingroup/outgroup differences, "racializing discourse" as Bonfiglio (2006) would have it, essentialising groups as "different" from others and creating artificial barriers to wider human interaction and cross-cultural understanding. Ethnicity is equally said to denote "marked", "non-mainstream", thus an ethnic 
Ezeifeka: Neologism and Nonce Expressions...

language is considered an ingroup way of speaking a national language (Wardhaugh and Fuller, 2015: 45). For instance, the Black American English is an "ethnolect" of the mainstream English language, a debased variety.

Ethnicity is said to have come to the fore after World War II when the term race was potentially discredited by its association with Nazism (Fishman, 1997: 328-329). Fishman regards ethnicity as fundamentally subjective, variable and very possibly nonconsensual. Fishman's assertion underscores Ukiwo's (2006) four explanatory framework, or what he has called motivations and/or tendencies for ethnic identity construction. These motivations are primordialism (bonded by kinship and common ancestry), constructivism (constructed in interaction to suit certain social purposes), instrumentalism (an extension of the constructivist view, which implies that ethnic identity is constructed to achieve emmanent goals) and finally, institutionalism (constructed group entrenched as stable and culturally normalized). Summing up the views of these two scholars therefore, ethnicity as a socially constructed alignment of people who see themselves as bonded by real or imaginary ancestry, but are in actual fact seeking common goals and interests through such alignments. As a sociolinguistic variable, the language one uses marks him/her as a member of a particular ethnic group.

In the same way, the neologisms found in our textual data tend to delineate the users' ethnic origin especially the most prominent ones that have tended to dominate the media: the Hausa-Fulani, Yoruba, Igbo, the Niger Delta and the Middle Belt ethnic nationalities. Nigeria is a country with over five hundred ethnic groups and languages (Blench and Dendo, 2003). These ethnic groups were lumped into two protectorates of North and South of the 1914 Lugardian era, thereafter in the three regions of North, South West and South East of the post independent era to which was later added the Mid-West in the pre-war era. As the nation progressed from twelve states, after the war, to nineteen, and now thirty-six states, plus the Federal Capital, these ethnic divisions have become more prominent and visible, each regarding itself as "ethnic nationality" and seeking right of recognition. That is why the "majority/minority" categorization of the National Language Policy in designating three "major" languages of Hausa, Igbo and Yoruba, 
as national languages have not been acceptable by the "minority" (National Policy on Education, 2004). It will therefore not be out of place to assert that Nigeria has been grappling with the problem of national integration since it came together as a nation and one of the factors in the front burner of this lack of understanding is ethnicity. Everyone thinks of him/herself as, first of all, a member of his/her ethnic group before being a Nigerian.

\subsection{The media as watchdog}

It has been argued, and reasonably too, that the symbolic names of some newspapers - Guardian, Vanguard, Sun, Voice, Trumpeter, Light, - point to the role of the media as the champion of the interest of the common person, the masses, those without access to power; and to enlighten them on the political situation of their society through authentic and objective reporting of events. It is on this basis that the media has been termed "the Fourth Estate of the Realm"; the legislature, executive and the judiciary being the first three estates (Watson and Hill, 2006). The media have thus been termed watchdogs of the people, as they owe the masses adequate and truthful representation of the events as they happen, as well as checkmate the excesses of the power elite.

However, because of the mediated nature of news reporting, some media renege on this watchdog role and become guard dogs and lapdogs for the power elite, skewing their reports to serve the interests of the powers that be. It is on this basis that the present work interrogates the media representation of the neologisms to determine the type of dog image they represent to the public which they are purported to serve.

\subsection{Theoretical Framework}

\subsection{Morphological processes}

One of the theoretical bases of this work is hinged on the morphological processes theory of lexical derivation or lexical morphology (Quirk \&Greenbaum, 1973; Matthews, 1974, 2006; Yule, 1985, 2010; Finegan, 2004). Four of these processes have been selected to drive the study: affixation, compounding, acronyms and coinages. As earlier discussed in the conceptual review, morphological processes of affixation involve both derivational and inflectional paradigms that are class-changing and class-maintaining 
Ezeifeka: Neologism and Nonce Expressions...

respectively. Whereas derivation involve both prefixes and suffixes attached to roots, bases and stems to derive new lexemes, inflections are usually always suffixes comprising a closed-set of eight morphemes that signal plurality and genitive (for nouns), tense/aspect (for verbal paradigms) and comparison (adjectives and adverbs). Our data relate not much with the formation and operation of the inflectional morphophonemic processes but more with how new lexemes gain entry into a language such as English, hence the focus of this paper on lexical derivational morphology.

Matthews (2006:62) claims that "a model of morphology, which is formally derivational applies to words in general and not just to relations between lexemes. He asserts that speakers invent or reinvent the model already established in word formation processes. Thus, we know the suffix -er, when added to the lexeme FARM will derive farmer the same way we understand that the word generation is from the root word generate and establishment from establish. Therefore, when presented with non-existent forms like reacter (one who reacts) or militation (something that militates against something else); they are intuitively understood by language users as derivational owing to the constancy of the derivational suffixes. This explains the creativity or productivity in the derivational process where one can create new forms even when such forms have never been heard before. Thus words like rare and brave can creatively take on Negative prefixes of in- (inrare, inbrave), un- (unrare, unbrave) or non- (non-rare, non-brave) and can be acceptable in nonce expressions such as "not an unrare situation" or "their relatively unbrave conduct". In this way, forms that may be nonce for a speaker, especially people in strategic positions such as apex ethnic leadership or the media, created on the spur of the moment to express certain state of affairs, can become established as neologism as a wider audience come to use them repeatedly. Matthews (2006) illustrates this with the word capsization (" a massive capsization in a few minutes"), though not a conventional English word, was used in a news broadcast and thus gained entry in common usage, with Matthews (2006) preferring the word capsizal if at all a word like that exists.

In the same way, compounding, acronyms and coinages seem to be productive nonce-forming processes useful in the analysis in this paper as has earlier been discussed. This paper identifies such nonce 
words and expressions with ethnic bias, which are steadily gaining popularity as neologisms as a result of the political and social standing of those who invented them. The position of these social actors in power structures in the country requires that these neologisms be subjected to critical discourse analysis.

\subsection{Critical Discourse Analysis}

Most of the neologisms and nonce expressions identified in this paper seem to presuppose underlying power structures which are either being contested and/or subverted. This concurs with the tenets of critical discourse analysis which sees texts as "sites of struggle" (Wodak, 2001: 8), sites where contending discourses struggle with one another for dominance. Fairclough (1995) has described CDA as a linguistic means of subverting oppression in its linguistic forms because, according to him, since language has the power to produce unequal power relations, language equally has the powerful potential of power subversion. Dominant ideologies reside in texts and if not identified and deconstructed, may become naturalized as common sense. CDA is thus a Marxist oriented means of interrogating dominant ideological positions by scrutinizing the utterances and actions of the power elite and bringing them up for demystification. It takes political stance explicitly by being overtly judgmental, leading some critics to regard the research agenda as advocacy. This criticism has already been neutralized by van Dijk's (2001:96) assertion that "CDA is biased (on the side of the oppressed) and proud of it"

Neologisms and nonce expressions identified in this work seem to provide the most accessible linguistic means of making the power elite aware of the effects of governance, either positive or negative, on the electorate. Words, in this case, are the weapons of the subjects vindicating the saying, 'the pen is mightier than the sword'. A listening government may, based on some of these neologisms, adjust their policies, change some existing laws or statutes, give more attention to grey areas of governance and propel them to initiate action to alleviate the sufferings of the subjects.

Fairclough's (1995) tri-dimensional framework to CDA will guide this study - linguistic level of description, semantic level of interpretation and pragmatic level of explanation. Whereas the linguistic level identifies the neologisms, interpretation of the 
Ezeifeka: Neologism and Nonce Expressions...

meaning implications of these neologisms will be done at the semantic level, while at the pragmatic level, the application of these meanings in the conduct of governance especially regarding ethnic politics will be explained.

\subsection{Methodology}

The paper adopts a qualitative approach to the analysis of samples from print and online newspapers that contain the relevant data for the study. Thus the criterion for selection of data sources is simply that they contain neologisms and nonce expressions. These are categorized according to the various word formation processes that produce such lexical items. Utterances from apex ethnic leaders and ethnic stakeholders from the five "major" ethnic complexes: North, South West, South East, South South and Middle Belt are implicated in the analysis. The period of the study categorized as the Change regime cover between 2015 to date.

Using Fairclough's tri-dimensional framework of discourse analysis in line with CDA, the neologisms and nonces are subjected to interpretation based on the context of their uses to determine their meaning implications. Thereafter, explanations of their pragmatic implications as regards ethnic politics and governance in Nigeria are attempted.

\subsection{Data Presentation and Analysis}

As mentioned earlier, the identified word formation processes fall into four categories, namely: affixation, compounding acronyms and coinages (in the form of complex nominalizations and hashtags). In the following tables, we present the identified neologisms and nonces according to their sources in the newspapers.

Table 1: Observed neologisms derived from Affixation in the newspapers

\begin{tabular}{|l|l|l|}
\hline S/N & Derived words & Source \\
\hline 1. & Restructuring & DailySun, Friday January 12, 2018: 1,12 \\
\hline 2. & Fulanization & Dailypost.ng, Friday, 26 Jan 2018 \\
\hline 3. & Cattle-cracy & $\begin{array}{l}\text { DailySunWednesday, January 24, 2018: } \\
48\end{array}$ \\
\hline 4. & Cattletocracy & Intersociety-ng.org, February 4, 2018 \\
\hline
\end{tabular}


Ogirisi: a new journal of African studies vol. 142018

\begin{tabular}{|l|l|l|}
\hline 5. & Buharism, & Sahara Reporters, May 3 2018 \\
\hline 6 & Buharists & The Whistlerng, May 16, 2018 \\
\hline 6. & $\begin{array}{l}\text { D- } \\
\text { Buharinisation }\end{array}$ & DailySun, Friday, March 31, 2017, p. 18. \\
\hline 7. & Youthocracy & Sahara Reporters 3 May 2018 \\
\hline
\end{tabular}

One of the most prevalent neologisms, which may not entirely be a new lexical item, but has acquired new meanings in the current media reports is the word restructuring from the base form "structure" which can function as a noun or a verb. As a noun, it means "the manner or act of putting together, constructing; the arrangement of parts" (The Chambers Dictionary, 2004:1639), and as a verb, "to organize, build up, to construct a framework...". The word restructuring, formed with the prefix re-and the suffix -ing to derive a verbal noun restructuring would denote a framework that is not firm, stable or solid and in dire need of fixing or repair. This lexical item has become a household word since it entered the national discourse, such that all ethnic stakeholders in Nigeria define it in accordance with the inherent merits or demerits to their ethnic groups. From our data, which may not all be represented here, it is evident that whereas all apex ethnic leaders of the South West, South East, South South and Middle Belt support restructuring the country along lines of true federal structure with a weak centre, the entire North, with the exception of the North Central and the Middle Belt resists it. The following texts illustrate this assertion. Text 1 is the famous "Handshake across the Niger" summit report. The headline reads:

Text 1: Handshake Across the Niger Summit: South East, South South dare Buhari

Team up with South West, North Central to insist on restructuring, demand action against herdsmen (DailySun, Friday, January 12 2018: 1, 12 by ChidiNnadi)

Some individual political leaders from the North have taken exception from the stance of the apex core north leadership on restructuring. According to them, that is the best way forward. 
Ezeifeka: Neologism and Nonce Expressions...

Text 2: Headline: Nigeria far behind many nations, restructuring the way forward - Dogara

Speaker of the House of Representatives, Hon. YakubuDogara has once again explained why he is clamouring for restructuring of the existing federal system of Nigeria. Dogara said the call for restructuring became imperative because it will give a sense of belonging to all Nigerians... The speaker noted that "the talk of Nigeria success or genuine federalism can no longer hold waters (sic) giving (sic) the state of internal insurgencies, divisiveness, ethnic and religious schism witnessed in several parts of Nigeria. Efforts at wishing away the problem associated with Nigerian Federation Laws only resulted into several tribal, ethnic and religious movements that have even metamorphosed into terrorist syndicates.

In spite of this strong argument in favour of restructuring by the apex leadership of the nation's Green Chamber, albeit from the North, many apex leaders of the North throw their weight against it, obviously for some ethnically motivated sentiments as evidenced in the text that follows.

Text 3: Headline: Forget Atiku, North will resist restructuring of Nigeria - AngoAbdullahi(SaturdaySun, March 17, 2018: 42-43,45)

The leader of the Northern Elders Forum (NEF), Prof AngoAbdullahi has declared that the region will resist any attempt to restructure the country...He concludes: "we have all personalized restructuring with a view to targeting a section of the country and this is the area that we feel very sensitive about and we will resist it. Even if we don't resist it objectively, we will resist it politically"

These calls to "restructure" the already structured nation have been attributed to a number of factors that have seemed to give rise to other neologisms. In the texts that follow, new lexical derivations 
Ogirisi: a new journal of African studies vol. 142018

such as "fulanisation" from the base "Fulani", "cattlecracy"/"cattletocracy" and "cowrisation" from "cattle" and "cow" respectively have been formed to explain the reasons for calls for restructuring.

Text 4: Headline: Obey Nigerian Constitution: Remove your Hausa-Fulani brothers as security chiefs - HURIWA tells Buhari. (Dailypost.ng, Friday, 26 Jan 2018).

A pro-democracy group, Human Rights Writers' Association of Nigeria (HURIWA) has told the Minister of Defence, retired Major General Mansur Dan-Ali to stop providing subtle justification for the dastardly criminal attacks by suspected Fulani herdsmen ... the group also called on President Buhari to respect constitutional provision of federal character principle and commence the immediate and comprehensive reconstitution of the national security team to reflect the federal character of Nigeria and end the ugly era of "fulanization" of national security team. The group insisted that the lopsided domination of security forces by HausaFulani ethnicity was a grave breach of the extant provision...

The word "brother" confirms Ukiwo's (2006) primordial criteria for ethnic alignment and exclusion and may have served as a motivation for nepotism being alluded to in the appointment of security chiefs which HURIWA regards as "fulanization" of national security. In the reports of DailySun, Wednesday, January 24, 2018: 48, the headline "Cattle-cracy" by the back page columnist, Dele Agekameh, has the root cattle suffixed by -cracy to denote cattle government a corruption of the term democracy. The author likened the Nigerian political space to that of George Orwell's dystopia Animal Farm.

Text 5:"In recent times, allusions have been made to Nigeria being a zoo, full of animals. One imagines what an animal government would look like in this 'zoo'. Of course, 
Ezeifeka: Neologism and Nonce Expressions...

cattle will run the show, due to their already immeasurable contributions and efforts towards colonization of humans as we have in Nigeria today. The first order of business for the animal government might be to suspend our laws and systems, to be replaced by a cattle-cracy ..." (government of the cattle, by the cattle for the cattle) (parenthesis mine)

Text 6: In the eye of local and international laws, it will also amount to official cementation, aiding and abetting of killing of Christians in Nigeria through a national policy of cattletocracy or state aided agrojihadist widespread violence against Christian population particularly in Nigeria. (Intersociety-ng.org, February 4, 2018)

All the above neologisms are seen as the fallouts of the "change" agenda which has been referred to in the next text as "Buharism" (the word buhariin Igbo means "change position" (from bad to good definitely)). This word was picked from the following text:

Text 7: Headline: Re: YeleSowore: The Latest Comedian in Town by SanyaoluJuwon. Sahara Reporters 3 May 2018.

...As I noted to the proponents of APCs Buharism, a vote for APC over PDP was already a vote for "continuity" since both are simply different feathers of the same bird...

All the supporters of the Change agenda are referred to as "Buharists" as shown in the following text credited to the social media aide to the presidency in response to why supporters were climbing trees to see the president in Jigawa state:

Text 8: Headline: Why people were climbing trees to see Buhari - Presidency Whistler ng May 16, 2018 "Buhari's supporters in Jigawa said, 'This is not Christmas tree. No. It's Buharists' (tree). It is Buharists doing all they will to welcome their leader to Jigawa State"

It is obvious from the text that follows that the case is different with non-supporters who allegedly implicate this change regime with 
sectional ethnic politics ; hence the negative prefix attached to the root/base of the word in the next text to show that the change has and needs to be changed.

Text 9: Headline: The Epistle of Apostle El-Rufai to St Buhari. DailySun, Friday, March 31, 2017: 18, by MajeedDahiru

"...if the APC will be reinvented, it has become expedient to denounce the presidency of Buhari as not the agenda of the party but the idea of Buhari and his sectional and incompetent kitchen cabinet... the APC must not only denounce Buhari, but must present a clear cut alternative to what is currently available. A process of D-Buharinisation (deBuharinisation?) will have to be carried out in the APC. The ruling party must move away as far as possible from the Buhari legacy of nepotism, cronyism, favouritism, ethnicism and regionalism collectively known as sectionalism".

Among the panacea for the change referred to above is another new lexical entry called "youthocracy" (Headline: Re: YeleSowore: The Latest Comedian in Town by SanyaoluJuwon. Sahara Reporters 3 May 2018), the conviction that the younger generation hold the solution to rescue the country from the abyss of self-destruction to which the old and "clueless" politicians have driven the country into. The next set of neologisms is listed in Table 2 and belongs to the word formation process of compounding. 
Ezeifeka: Neologism and Nonce Expressions...

Table 2: Samples of Compounding neologisms observed in the media reports

\begin{tabular}{|l|l|l|}
\hline S/N & Compounding & Source \\
\hline 1. & $\begin{array}{l}\text { Self- } \\
\text { determination }\end{array}$ & Punch. Punch.ng.com. Feb.15, 2018 \\
\hline 2 & Quit notice & http://sunnewsonline.com. June 6,2017 \\
\hline 3. & Cattle colony & SaturdaySun, January 27, 2018, p. 11 \\
\hline 4. & Killer herdsmen & $\begin{array}{l}\text { Naija } \\
\text { www.naijaloaded.com.ng/News. Feb. 18, } \\
\text { 2018 }\end{array}$ \\
\hline 5. & Kitchen cabinet & DailySun, Friday, March 31, 2017: 18, \\
\hline 6. & Nepotic court & $\begin{array}{l}\text { DailySun, Wednesday, January 24, 2018, } \\
\text { p. 1,4, }\end{array}$ \\
\hline 7 & Third force & $\begin{array}{l}\text { DailySun, Wed., January 24, 2018:1\&4, } \\
\text { SundaySun April 29 2018:11 }\end{array}$ \\
\hline 8. & NNPCgate & DailySun, Monday, October 9, 2017, p.8 \\
\hline 9 & Hate Speech & DailySun, Friday, January 26, 2016, p.6 \\
\hline 10 & Grazing routes & DailySun, Friday, January 26, 2016, p.6 \\
\hline 11 & $\begin{array}{l}\text { Cattle } \\
\text { rustling/rustlers }\end{array}$ & $\begin{array}{l}\text { Metro News, Naijanews.com, January 29, } \\
\text { 2018 }\end{array}$ \\
\hline 12. & State ranches & DailySun, Jan 16, 2018, p. 6 \\
\hline 13 & Vote buying & DailySun Friday, February 9, 2018, p.3 \\
\hline 14 & Babasanjo & SaturdaySun, Feb. 3 2018, p. 37 \\
\hline & &
\end{tabular}

Most of the compound formations in Table 2 have become regular usages in the print and online media. Self-determination (see Text) bid has been a word at the back of Biafra agitations leading to the Arewayouths declaration of June 62018 of the infamous but subsequently retracted quit notice to the Igbo living in the north. The word "quit notice" is legal term normally used in landlord/tenant interaction where the tenant breaches the terms of occupancy and is served notice of ejection.

Of interest are also the reasons adduced in the next text about the bloodletting of killer herdsmen.

Text 10: Headline: Security agencies spy on Nigerians:

DailySun Friday January 26, 2016, p. 6

-As FG begins social media monitoring -Buhari, security chiefs hold parley 
Taraba killings

-anti-open grazing laws blamed for Benue,

Minister of Defence ... told State House Correspondents after the meeting (with security chiefs) that there was the need for the relevant security agencies to as a matter of urgency tackle "the propagation of hate speeches especially through the social media and particularly by some notable Nigerians ... the minister revealed that the council also discussed the remote and immediate causes of the frequent farmers/Fulani herdsmen deadly clashes in the country, which he blamed on the blockage of cattle routes and the establishment of anti-grazing laws by some states and the existence of local militias...

Many commentators have questioned the need of social media monitoring since it is difficult to determine between hate speech and constructive criticism. It is also not clear to many where and when these grazing routes were earmarked and whether such hackneyed practices are still sustainable in the present era.

Giving another reason for the killer herdsmen killing of people in their host communities, the following text gives a parallel view.

Text 11: Headline: Why Fulani Herdsmen Kill - Former Vice Chancellor of Ahmadu Bello University Speaks. Naija News www.naijaloaded.com.ng/news. February 18, 2018.

A former Vice Chancellor of Ahmadu Bello University, and spokesperson of the Northern Elders Forum (NEF) ... has vehemently defended the incessant killings by Fulani herdsmen across the country. Abdullahi also said that the herdsmen menace was politically motivated by the South to disrupt the politically united North ahead of the 2019 general elections, adding that this was how Boko Haram was introduced during Goodluck Jonathan's government which led to his failure in 2015 polls. Justifying the killings, the professor said that the herdsmen are (sic) killing members of their host communities in order to defend themselves, adding that the herders were free to take their cattle to any 
Ezeifeka: Neologism and Nonce Expressions...

part of the country the same way an Igbo man does his business...

The ethnic implications of the above neologisms are obvious. The defence being referred to is the defence of their cows as the next text (Text 11) illustrates, leading to the call for cattle colonies in Text 12.

Text 12: Headline: Cattle rustlers kill 73 cows; injure 18 in Nasarawa. Naija News by Ibukun Josephine Bankole, January 29, 2018).

Text 13: Headline: No going back on cattle colonies - FG. (SaturdaySun, January 27, 2018: 11, 47, 48

...though the Federal Government will not force any state to provide land for the project... the Federal Government's proposal to set up cattle colonies and the encouragement of ranches remained the best option to the killings and toxic hatred the current altercation had generated... the wanton loss of lives was not acceptable...

The nonce expression "Babasanjo", is a derivation of two words from Yoruba, "Baba" meaning "Father", and "sanjo" from the last morpheme of the ex-President "Obasanjo". This formation was sequel to the open letter to the President asking him to quit governance in 2019 because of failure of his government on all counts of his campaign promises of Change: political and economic security, lopsided appointments, foreign policies, insurgencies and other considerations such as age and health status. This nonce is a corruption of the name of the speaker who is playing father role in spite of not doing any much better when the lot fell on him to perform the tasks he is accusing his successor of reneging on. The report reads:

Text 14: Headline: When I grow up, I want to be likeBabasanjo! SaturdaySun, Feb. 3 2018, p. 37. By Usoro I. UsoroThe Reality. 


\begin{tabular}{|l|l|l|l|}
\hline S/N & Acronyms & Full Meanings & Source \\
\hline 1. & IPOB & $\begin{array}{l}\text { Indigenous People of } \\
\text { Biafra }\end{array}$ & $\begin{array}{l}\text { (punchng.com/...). February } \\
15,2018\end{array}$ \\
\hline 2. & YOLICOM & $\begin{array}{l}\text { Yoruba Liberation } \\
\text { Command }\end{array}$ & $\begin{array}{l}\text { Press Release: July 27, 2017, } \\
\text { Declare Oduduwa Republic, } \\
\text { World Press Conference, } \\
\text { International press Centre, } \\
\text { Lagos }\end{array}$ \\
\hline 3. & Rondel & $\begin{array}{l}\text { Region of the Niger } \\
\text { Delta }\end{array}$ & $\begin{array}{l}\text { Press Release: A demand for } \\
\text { Independence of Rondel in } \\
2018\end{array}$ \\
\hline 4. & AYCF & $\begin{array}{l}\text { Arewa } \\
\text { Consultative Forum } \\
\text { Middle Belt Youth } \\
\text { Council }\end{array}$ & $\begin{array}{l}\text { http://sunnewsonline.com. } \\
\text { June 6,2017 } \\
\text { punchng.com/...). February } \\
15,2018\end{array}$ \\
\hline 5 & MBYC & $\begin{array}{l}\text { Ijaw Youth Council } \\
\text { (punchng.com/...). February } \\
15,2018\end{array}$ \\
\hline 7 & CNM & $\begin{array}{l}\text { Coalition for Nigeria } \\
\text { Movement }\end{array}$ & $\begin{array}{l}\text { DailySun, Tuesday, January } \\
23,2018\end{array}$ \\
\hline
\end{tabular}

\section{Table 3: Samples of Acronyms}

The following text from Punch online aptly illustrates the proliferation of acronyms with ethnic bias in the media which has gained much prominence in the past few years. This proclivity to segregational ethnic politics has seemed to mar ethnic cohesion and national integration. Worthy of note is the fact that none of the "pressure groups" in Text 15 is from the north which seems to concur with the text where the chairman of the Northern Elders Forum states vehemently that "the North will resist restructuring"

Text 15: Headline: Lawyer sues FG, seek right for selfdetermination (punchng.com/...). February 15, 2018

A lawyer Chief Malcom Omirhobo has sued the Federal Government, urging he court to hold that there is no law stopping citizens from any part of the country from seeking self-determination if they so want.... Omirhobo filed the 
Ezeifeka: Neologism and Nonce Expressions...

lawsuit on behalf of himself, 373 ethnic nationalities and 45 pressure groups agitating for self-determination in the country. The pressure groups listed as plaintiffs in the suit include: Indigenous People of Biafra (IPOB), the Movement for the Survival of the Ogoni People(MOSOP), the Niger Delta People's Volunteer Force (NDPVF), the Niger Delta Agitators (NDA), Pan Niger Delta Elders Forum (PANDEF), Niger Delta Freedom Mandate (NDFM), Niger Delta Development Network (NDDN), Niger Delta Freedom Redemption, (NDFR), Movement for the Actualization of Niger Delta People's Republic (MANDPR), Niger Delta Movement for Justice (NDMJ), Niger Delta Patriotic Front (NDPF), Niger Delta People's Fighter (NDPF), and the Coalition of Niger Delta Agitators (CONDA).

Also listed as plaintiffs are the Bakassi Freedom Fighters (BFF), Niger Delta Watchdog (NDW), Urhobo Progressive Union (UPU), Niger Delta Congress (NDC), Niger Delta Liberation Force (NDLF), Niger Delta Red Squad (NDRS), Asawana Deadly Force of the Niger Delta (ADFND), Niger Delta Revolutionary Crusaders (NDRC), Red Igbesu Water Lion (RIWL), Niger Delta Afra Descendant Movement (NDADM), Ijaw Youths Council (IYC), UhroboGbagbako (UG).

Others are Afenifere, Oodua People's Congress (OPC), Oodua Nationalist Coalition (ONC), Oodua Liberation Movemen (OLM), Oodua Republic Coalition (ORC), Yoruba Revolutionary Congress (YRC), Oodua MuslimChristian Dialogue Group (OM-CDG), Yoruba Students' Nationalist Front (YSNF), Oodua Hunters Union (OHU), Coalition of Oodua Self-determination Group (COS-DG), the Middle Belt Forum (MBF), the Middle Belt Youth Council (MBYC), United Middle Belt Congress (UMBC) and the Northern Central Unity Bridge (NCUB)

According to the above report, a total of "373 ethnic nationalities and 45 pressure groups agitating for self-determination" are behind this lawsuit. For all these acronyms of fragmentation to exist in our national structure show a nation on a shaky framework in need of some kind of repair for better ethnic and national cohesion. 


\section{Table 4: Samples of Coinages in the media}

Two types of this word formation process are observed: complex nominalizations and hashtags.

\section{Table 4a: Samples of Complex Nominalizations}

\begin{tabular}{|l|l|l|}
\hline S/N & Complex Nominalizations & Source \\
\hline 1. & $\begin{array}{l}\text { Operation python dance } \\
\text { (Egwu Eke) }\end{array}$ & $\begin{array}{l}\text { https://guardian.ng>news } \\
\text { February 3, 2018 }\end{array}$ \\
\hline 2 & $\begin{array}{l}\text { Operation crocodile smile } \\
\text { https://guardian.ng>news } \\
\text { February 3, 2018 }\end{array}$ \\
\hline 3. & $\begin{array}{l}\text { Operation Cat Race } \\
\text { Ayem a Kpatema) }\end{array}$ & $\begin{array}{l}\text { https://guardian.ng }>\text { news } \\
\text { February 3, 2018 }\end{array}$ \\
\hline 5 & $\begin{array}{l}\text { Operation Lafia Dole } \\
\text { Niger }\end{array}$ & $\begin{array}{l}\text { https://guardian.ng>news } \\
\text { February 3, 2018 }\end{array}$ \\
\hline 5
\end{tabular}

The nominal groups in Table 4(a) illustrate the various rhetoric by the power elite and the masses to subvert opposition or suppression, respectively. In the following text, a media columnist is calling the integrity of the government to question by querying the selective declarations of military operations to contain security threats in some parts of the country

Text 16: Headline: Waiting for Operation Scorpion Sting in the Middle Belt. DailySun, Friday, January 23, 2018, p. 48 (back page) by OnuohaUkeh

"...In the past, the government had declared military actions/operations to arrest situations. In recent times, we heard of 'Operation Python Dance' in the South East, we heard of 'Operation Crocodile Smile' in the South South, we heard of 'Operation Lafiya Dole' in the North East. In justifying these operations, the government told Nigerians the actions were declared to bring about peace and restore security. Now, there is a bad situation in the North Central. The onus lies on government to handle it like it did others, including those of less consequence. If something like 
Ezeifeka: Neologism and Nonce Expressions...

'Operation Scorpion Sting' against herdsmen is not declared, it will be obvious that there is double standard in the conducts of the government...".

Invariably, this columnist is querying the efficacy of "Operation Cat Race" (Ayem a Kpatema) in the North Central and seeks a more virulent military presence to quell the incessant security threats of the region.

\section{Table 4b: Samples of Coined Hashtags}

\begin{tabular}{|l|l|l|}
\hline S/N & Hashtags & Source \\
\hline 1 & \#BringBackOurGirls & DailySun \\
\hline 2. & \#OurMumuDonDo & Sahara Reporters, October 15, 2017 \\
\hline 3 & \#TheCabalMustGo\# & \\
\hline 3. & \#TakeItBack & Sahara Reporters, May 3, 2018 \\
\hline 4 & \#NotTooYoungToRun & $\begin{array}{l}\text { Pulse News Agency Local by } \\
\text { NANS. Opera.pulse.ng/news/local/. }\end{array}$ \\
\hline 6. & \#LazyNigerianYouth & $\begin{array}{l}\text { DailySun, Wednesday, April 18, } \\
\text { 2018, }\end{array}$ \\
\hline 7. & \#LazyNorthernYouth & DailySun \\
\hline 8 & \#NinetySeven /Five & Vanguard, July 23, 2015 \\
\hline
\end{tabular}

The hashtags represent utterances of the power elite and attempts by Nigerians to respond to them. For want of space, not all of them will be illustrated although textual samples abound in the print and online media as shown in the Table $4 \mathrm{~b}$.

Every print or online media reader would have come across many of these new lexical entries in our national discourse such as \#OurMumuDonDo initiated by Charles Oputa (Charly Boy) to protest the continuous absence of the president on medical leave and other social ills, \#TheCabalMustGo by Braimah in response to the recycling of the same personalities in governance since the country's independence, \#BringBackOurGirls by ObyEzekwesili and Aisha Yesufu to agitate for the release of the 2014 and 2017 abducted Chibok and Dapchi girls respectively. Though \#BBOG came into national discourse in 2014, it has persisted till date because of nonrelease of some of the abducted girls of Chibok, and the current 
Dapchi abduction which has one girl, Leah Sharibu still in captivity, allegedly because she refused to denounce her faith. The \#LazyNigerianYouth/\#LazyNorthernYouth were coined to protest the president's alleged "de-marketing" of Nigerian youths during his trips to the UK and USA respectively.

The following texts will also illustrate the hashtags coined for youth participation in politics in furtherance of "youthocracy" mentioned above.

Text 17: Headline: CSOs appeal to National Assembly to transmit Not-Too-Young-To-Run Bill for assent. Pulse News Agency Local by NANS. Opera.pulse.ng/news/local/. May 9, 2018 by MoshoodIsah

Text 18: Sowore 2019: TakeItBack Movement. “...let's take back our country. OmoyeleSowore for President! ... Now is the time to fight the arrogant oppressors out of power and to \#TakeItBack. And this we will do by aligning ourselves with a mass-based movement

\subsection{Discussion}

From our analysis of the neologisms and applying our tridimensional analytical framework, it is evident that words are powerful tools for constructing and representing experiences, worldviews and identities in the daily course of human interaction within the different sociolinguistic variables, one of which is ethnicity. The different neologisms that form our textual data were found to have been derived, invented/coined, compounded or formed from existing or new forms to capture the events of the political situation in Nigeria which tend to have degenerated to ethnic alignments and exclusion. Far from synergizing the multifarious ethnic nationalities, with varying degrees of potentials to drive the country to national integration and sustainable development, these divisive tendencies continually and systematically drive the country to disintegration and disunity.

The neologisms are garnered from the utterances of the power elite as well as the subjects. Some utterances of the power elite have been implicated as driving sectional politics which favour some ethnic groups and disadvantage others and this has been ascertained by 
Ezeifeka: Neologism and Nonce Expressions...

certain actions and inactions of government. For instance, the famous ninety-seven/five lopsided ratio of voters to which the country has been polarized in terms of appointments and development indices will always be a new word formation that tends to have driven ethnic politics along lines of alignments and exclusion. Coinages like "Handshake across the Niger" (with a recent suggestion for a similar "handshake" across Benue), and the different hashtags would constitute a response to this exclusion as affected ethnic groups synergise to work out solutions to the alleged marginalization, underrepresentation and exclusion from the scheme of things. This has led to proliferation of pressure groups, alignments and realignments of ethnic identity construction illustrated by the numerous acronyms on Table 3 and Text 14. Similarly, such derived words as "Buharism", and "Buharists" which invariably denotes "Change", and its negative variant, "D-Buharinization" represent two sides of ideological struggle, one calling for the sustenance of the regime while the other is advocating for changing the "Change". This cacophony of voices, given vent through the neologisms in this study, has grave implications for ethnic cohesion and national integration. Firstly, the sustained call for restructuring the country along six geopolitical zones, the self-determination bid championed by (IPOB) for the sovereign state of Biafra, to be followed by the Yoruba Liberation Command (YOLICOM) for Oduduwa Republic, Pan Niger Delta Forum for the Republic of the Niger Delta (Rondel) and the Middle Belt Republic, are all efforts to resist the perceived marginalization of these ethnic groups by the government in power. Secondly, the general feeling of obvious militarization of certain parts of the country with violent military operations while leaving some places where such military operations are urgently required to stem incessant killing of innocent citizens by some armed killer herdsmen leaves much to be desired in ethnic cohesion and national integration in Nigeria. Thirdly, the feeling that the change agenda has failed in its three point campaign promises to Nigerian on fighting corruption, revamping the economy and restoring security of Nigerians from insurgencies has led to the proposal of alternatives such as restructuring, the "Third Force" also called "Coalition for Nigeria Movement" (CNM), "youthocracy", the call on the youth to \#TakeItBack from the older generation, the various hashtags such as 
\#OurMumuDonDo. \#BBOG, \#TheCabalMustGo. At present, there seem to be no way out.

\section{Conclusions and Recommendations}

This work has tried to bring to the fore the many new lexical entries in the political discourse of the present regime and how these new words seem to tilt towards ethnic segregation and exclusion. Necessity, they say, is the mother of invention, thus these neologisms are invented to address urgent societal ills. It is obvious that the present situation is unsavoury and inimical to national integration. Rather than see some of these neologisms as negative signals of critique or the extreme case of terming some as "hate speech", the power elite should see them as vents for public opinion assessment, for making the pulses of the governed to be felt by those in power who may be very far removed from their realities.

The governed should equally "sanitize" their utterances especially in the social media so that constructive criticisms which could help the government understand the needs of the populace are not misconstrued as hate speech. The media should equally censor their publications, such that, while performing their role of objective reportage as champions of public interest and custodian of authentic news, they should be wary in their choice of words or invention of new ones so that they do not incite their reading audience to the wrong courses of action.

*ChinweRoseAnnEzeifeka, PhD,Department of English Language and Literature, NnamdiAzikiwe University Awka, Nigeria chiezeifeka@gmail.com 
Ezeifeka: Neologism and Nonce Expressions...

\section{References}

Bauer L. English Word Formation. Great Britain: Cambridge University Press, 1983.

Blench, R. and Dendo, M. (2003). The dimensions of ethnicity, language and culture in Nigeria. Cambridge:Department of International Development. Accessed 9 Sept 2017 www.rogerblench.info/Development/Nigeria/Economic\%20develop ment/Ethnicity\%...

Bonfiglio, T.P. (2007). Language, racism and ethnicity. Handbook of language and communication, diversity and change.Hellinger, $\mathrm{M}$. and Pauwels, A. (eds). De Gruyter and Mouton. 619-650.

Crystal, D. (2003). A dictionary of linguistics and phonetics. (5th ed.) Malden: Blackwell.

Fairclough, N. (1995). Critical discourse analysis: The critical study of language. England:

Longman Group Ltd.

Finegan, Edward. (2004). Language, Its Structure and Use. $4^{\text {th }}$ ed. Boston: Wadsworth.

Fishman, Joshua. (2000). Language and ethnicity: The view from within. A Handbook of Sociolinguistics. Florian Coulmas (Ed). Massachusetts: Blackwell, pp327-343.

Matthews, P.H. Morphology. 2nd ed. Cambridge: Cambridge University Press, 1991.

National Policy on Education. 4th ed. National Educational Research and Development Council (NERDC), 2004.

Quirk, Randolph. And Sidney Greenbaum. A University Grammar of English. Edinburgh: Pearson Education Ltd, 2000. 
Ogirisi: a new journal of African studies vol. 142018

Singh Ishtla. (2000). Language and ethnicity. Language, society and power. An introduction. Thomas, L and Wareing, S. (eds.). London: Routledge. 83-96.

Ukiwo, Ukoha. (2005). The study of ethnicity in Nigeria. Oxford Development Studies 33(1) pp. 7-23

Van Dijk, T.A. (1993). Elite Discourse and Racism. London: Sage

Van Dijk, T.A. (2001). Multidisciplinary CDA: A plea for diversity. In R. Wodak and M. Meyer (Eds.), Methods of critical discourse analysis. London: Sage. 95-120.

Wardhaugh, Ronald \& Fuller, Janet M. (2015). Introduction to Sociolinguistics $7^{\text {th }}$ ed. West Sussex: Wiley and Sons.

Watson, J. and Hill, A. (2006). Dictionary of media and communication studies (7th ed.) London: Hodder Arnold.

Wodak R (2001). What CDA is about: A summary of its history, important concepts and its developments.In R. Wodak and M. Meyer (Eds.), Methods of critical discourse analysis (pp. 1-13). London: Sage.

Yule, G. (1985). The Study of Language. Cambridge: Cambridge University Press.

Yule, G. (2010). The Study of Language. $4^{\text {th }}$ ed. Cambridge: Cambridge University Press. 